\title{
ЗАСТОСУВАННЯ КОРПУСНИХ ТЕХНОЛОГІЙ У ДОСЛІДЖЕННІ ХУДОЖНЬОГО ПОРІВНЯННЯ (НА МАТЕРІАЛІ АНГЛІЙСЬКОЇ ПОЕЗІЇ ПОЧАТКУ ХІХ СТОЛІТТЯ)
}

Анотація. Пропонована стаття присвячення розкриттю проблематики застосування корпусних технологій у дослідженні поетичного тексту, продуктивності корпуснобазованого підходу до опрацювання великих масивів мовного матеріалу. Метою статті є виявити структурні та семантичні особливості художнього порівняння в англійському поетичному дискурсі початку XIX століття за даними корпусного дослідження. Емпіричним матеріалом слугували поезії Семюела Тейлора Колріджа, Персі Біші Шеллі та Джона Кітса. Для мети дослідження був укладений корпус поетичних текстів вказаного історичного періоду, який охоплюе авторські підкорпуси поетичних текстів, загальна кількість слововживань яких становить 50000 слів. Створений та розмічений корпус текстів та відповідні програмні інструменти дали змогу виконати частотний аналіз лексичних засобів вербалізації виділених у текстах кожного автора художніх концептів та пошук і семантичний аналіз порівняльних засобів вербалізації цих концептів та здійснити їхню класифікацію.

Ключові слова: корпус текстів, корпусна лінгвістика, англійська поезія, художне порівняння, Семюел Тейлор Колрідж, Персі Біші Шеллі, Джон Кітс.

Romanyshyn Nataliia, Liadyk Zoriana Lviv Polytechnic National University

\section{APPLICATION OF CORPUS TECHNOLOGIES IN THE STUDY OF ARTISTIC COMPARISON (BASED ON THE ENGLISH POETRY OF THE EARLY 19TH CENTURY)}

Summary. The article is devoted to the disclosure of the problems of corpus technologies application in the study of poetic text, the productivity of the corpus-based approach to the processing of large arrays of language material. The aim of the article is to identify the structural and semantic features of artistic comparison in the English poetic discourse of the early nineteenth century according to corpus research. The empirical material was the poetry of Samuel Taylor Coleridge, Percy Bysshe Shelley and John Keats. For the purpose of the research, a corpus of poetic texts of the specified historical period was created, covering the author's subcorpora of poetic texts, the total number of word usages of which is 50,000 words. The created and marked corpus of texts and corresponding software tools made it possible to perform the frequency analysis of lexical means of verbalization of artistic concepts highlighted in the texts of each author and perform the semantic analysis of comparative means of verbalization of these concepts and classify them. The study obtained data on the configuration and frequency of comparative means of verbalization of integrated conceptual / mental fields and artistic concepts of English poetry of the early nineteenth century. he main mental spaces and their conceptual content in the poetic works of all studied authors are identified and described; the analysis of structural and compositional forms of artistic comparison is carried out. The analysis of structural-compositional and semantic aspects of the processes of artistic conceptualization in the system of artistic comparisons is the basis for determining the artistic and aesthetic principles of the worldview of English poets of the early nineteenth century. Accordingly, the dominant conceptual areas are nature, man and the world, actualized in the system of artistic and poetic concepts that reveal the anthropocentric nature of the poetic reflection of reality, the selection of sensory, psycho-emotional, mental characteristics of the subject of poetic image, human-oriented image of the world.

Keywords: corpus of texts, corpus linguistics, English poetry, artistic comparison, Samuel Taylor Coleridge, Percy Bysshe Shelley, John Keats.

$\Pi$ остановка проблеми. У результаті становлення корпусної лінгвістики як самостійної галузі сучасного мовознавства ідея корпусу лягла в основу нового підходу до розуміння й дослідження мови. Створення й використання корпусу грунтуеться на теоретичних принципах емпіричного дослідження мови $[1 ; 14$, с. 180]. У цьому контексті корпус як система цінуеться завдяки своїй багатофонкціональності, інтерактивності, придатності до широкого використання в теоретичних і практичних дослідженнях мови залежновідтипівдослідницькихпитань [4; 16;17]. 3 кожним роком кількість корпусів, доступних для використання, збільшуеться. Розширюеться і коло завдань використання корпусних технологій у вивченні мовних та мовленнєвих феноменів, системних та типологічних ознак різних типів текстів. Сучасна корпусна лінгвістика та методологія корпусних досліджень має особливе значення у досліджені художнього тексту в аспекті його лексико-стилістичних параметрів: передусім специфіки вербалізації образної системи художнього тексту, вибудовування семантичних доменів на основі частотності та дистрибущії ключових слів тощо. Новим напрямком у використанні корпусних технологій є аналіз структурних та семантичних особливостей тропів та стилістичних засобів авторської образності, зокрема художнього порівняння.

Аналіз останніх досліджень та публікацій. Представники різних течій мовознавства пропонують різноманітні підходи до трактування художнього порівняння. Розуміючи порівняння як засіб «смислетворення, що впливає на 
формування тексту і грунтується на особливостях людського мислення зіставляти явища навколишньої дійсності» [11, с. 120], мовознавці аналізують його в різних аспектах: семантичному (у працях Г. Кривенко [3], Ю. Маковецької-Гудзь [6], А. Найди [7], Т. Павлюк [8], С. Талько [9], А. Шевчук [12] та ін.); фрункціональному та прагматичному ( у працях Л. Ікалюк [2], О. Тищенко-Монастирської [10], Г. Кривенко [3] та ін.); лінгвокогнітивному (Н. Ярова [13]) гендерному (О. Левченко [5]) тощо.

Метою цього дослідження $є$ виявити структурні та семантичні особливості художнього порівняння в англійському поетичному дискурсі початку XIX століття (на матеріалі поезії Семюела Тейлора Колріджа, Персі Біші Шеллі та Джона Кітса) за даними корпусного дослідження.

Виклад основного матеріалу дослідження. Укладений для мети нашого дослідження корпус поетичних текстів вказаного історичного періоду охоплює авторські підкорпуси поетичних текстів, загальна кількість слововживань яких становить 50000 слів.

Для опрацювання корпусних даних було написано три програми. Перша застосована для перетворення Excel-райл в текстовий, для аналізу словоформ. Файл електронної таблиці Excel містить інформацію про поета (автора тексту), тип ключового слова, предмет зображення, концепт, структура порівняння та саме порівняння. Для перетворення фрайлу здійснювалось підключення додаткові бібліотеки Python. Бібліотека "openpyxl" (використовуеться для опрацювання Excelфайлів). Вона допомагає здійснювати читання та запис інформації у файли електронних таблиць dормату xls та xlsx. Бібліотека "os" надає безліч функцій для роботи з операційною системою, причому їх поведінка, як правило, не залежить від OC, тому програма може бути кросплатформенною. Цей модуль потрібен для пошуку та доступу до фрайлів на диску. Бібліотеки "sys" та "glob" дозволяють отримати доступ до внутрішніх налаштувань операційної системи та інтерпритатора Python. Це дозволить забезпечити роботу програми у різних версіях Python. Бібліотека "collections" надає доступ до спеціалізованих типів даних, на основі словників, кортежів, множин та списків. 3 ціеї бібліотеки імпортуеться модуль словників.
Отримавши доступ до програмних інструментів обробки текстових даних та стандартних бібліотек, переходимо до аналізу самих фрайлів (рис. 1).

У рядку 60-61 створюеться результуючий текстовий файл, в який буде вноситись відповідна інфрормація. Далі, для кожного Excel-фрайлу здійснюється пошук по усіх аркушах фрайлу відповідної інфрормації та їі запис у текстовий фрайл.

На наступному етапі потрібно здійснити аналіз тексту та сформувати статистичну інформацію. Для цього було використано програму "CalcComparison.py". Використовуючи словник спеціалізованих типів даних програма формуе наступні дані:

- Розподіл кількості порівнянь за поетами;

- Розподіл типів ключових слів за назвами;

- Розподіл предметів зображення за назвами;

- Розподіл концептів за назвами;

- Розподіл структур порівнянь за назвами.

Також у програмі передбачена функщія, яка формує статистику за відповідно заданими параметрами у поетичних підкорпусах (за іменем автора). Для кожного автора, дана фрункція фрормує таку інформацію:

- Розподіл типів ключових слів за назвами;

- Розподіл предметів зображення за назвами;

- Розподіл концептів за назвами;

- Розподіл структур порівнянь за назвами.

Таким чином, створений та розмічений корпус текстів та відповідні програмні інструменти дали змогу виконати частотний аналіз лексичних засобів вербалізації виділених у текстах кожного автора художніх концептів та пошук і семантичний аналіз порівняльних засобів вербалізації концептів та здійснити їхню класифікацію. В результаті ми отримали дані про конфігурацію та частотність порівняльних засобів вербалізації інтегральних концептуальних/ментальних полів та художніх концептів англійської поезї̈ початку XIX століття.

Ми розглянули частотний розподіл контекстів художнього порівняння у поезії досліджуваних авторів. Виявлено: художне порівняння є одним 3 найчастотніших способів художньої концептуалізації. Практично рівномірний розподіл художніх порівнянь у текстах авторів свідчить про продуктивність образного світосприйняття та відображення предметів художнього зображення

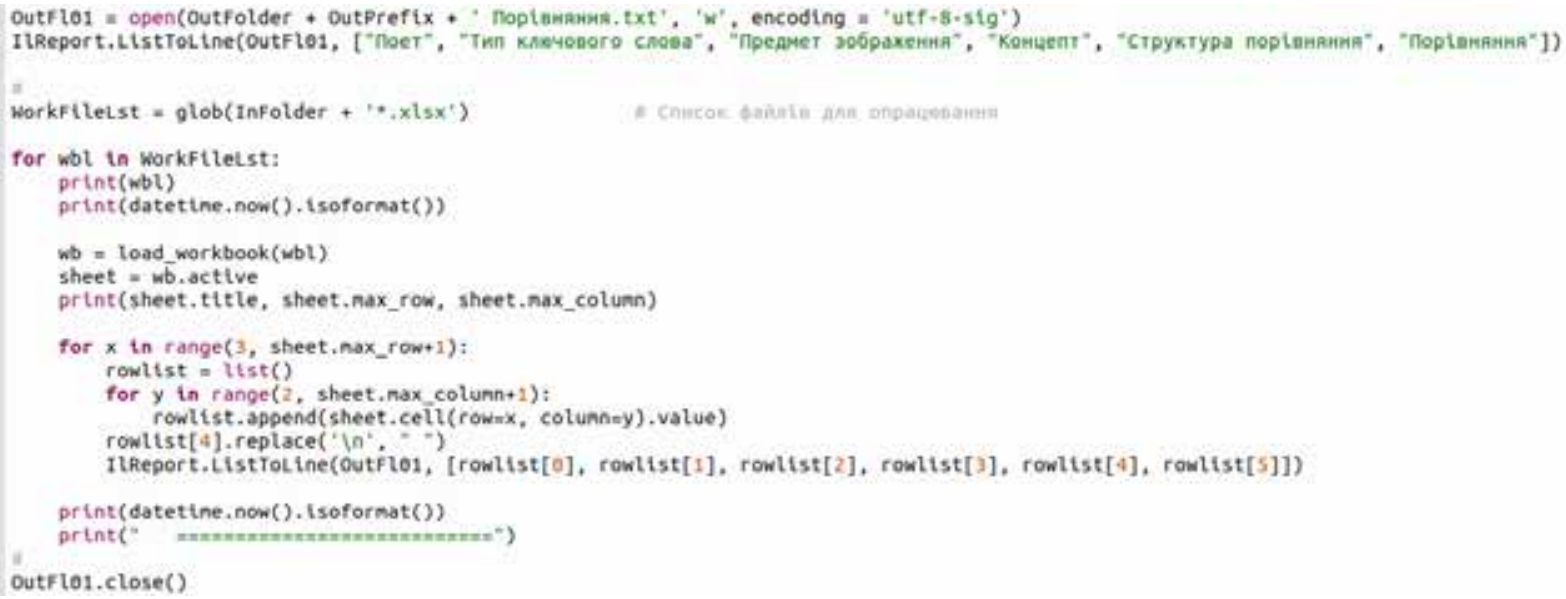

Рис. 1. Обробка xlsx-файлів 
на основі численних асоціацій та ментальних операціях уподібнення і порівняння. Розподіл порівнянь у поезії Колріджа, Шеллі та Кітса (таблиця 1) та (рис. 2).

Кількісне співвідношення порівнянь у поетичних дискурсах Колріджа, Шеллі та Кітса

\begin{tabular}{|c|c|c|}
\hline Значення & Кількість & Частота \\
\hline Coleridge & 92 & $32 \%$ \\
\hline Keats & 83 & $28 \%$ \\
\hline Shelley & 117 & $40 \%$ \\
\hline Paзом & 292 & $100 \%$ \\
\hline
\end{tabular}

Джерело: розроблено авторами

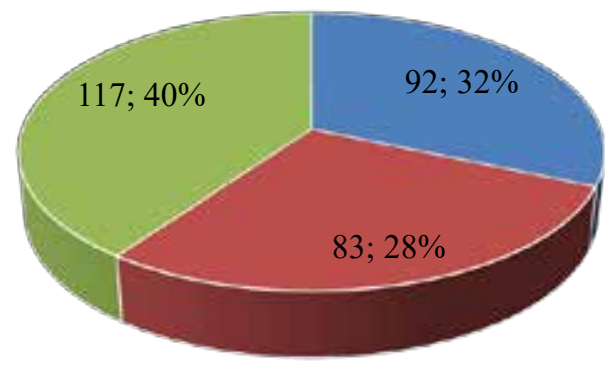

- Coleridge $\quad$ Keats $\square$ Shelley

Рис. 2. Розподіл художніх порівнянь у поезії Колріджа, Шеллі та Кітса

Джерело: розроблено авторами

Важливим етапом статистичного аналізу було встановлення співвідношення лексико-граматичних типів порівнянь, визначених на основі сполучного компонента порівняння: like, as, seem. Сукупно у всіх поетичних контекстах найчастотнішим виявилося ключове сполучне слово like (таблиця 2 та рис. 3 ).

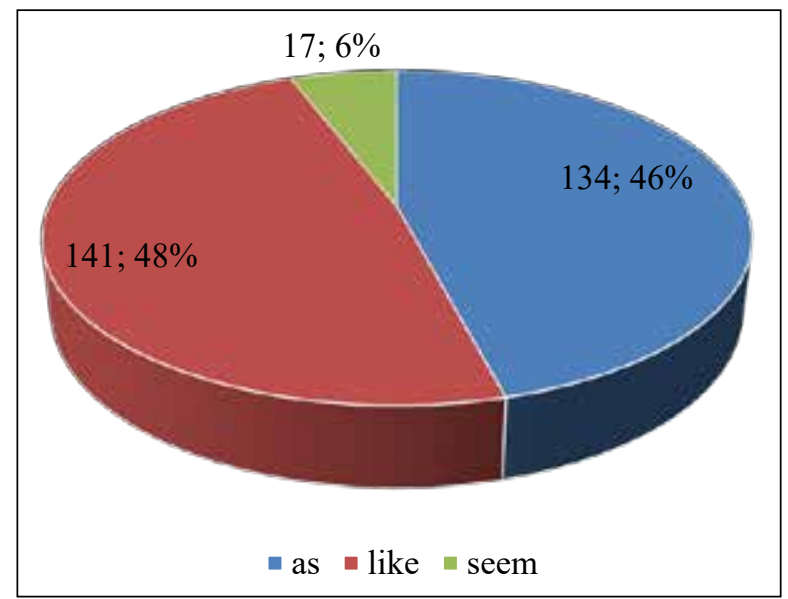

Рис. 3. Співвідношення частотності сполучного елемента порівняльних структур у поетичних дискурсах Колріджа, Шеллі та Кітса

Джерело: розроблено авторами
Таблиця 2

Розподіл частотності сполучного елемента порівняльних структур у поетичних дискурсах Колріджа, Шеллі та Кітса

\begin{tabular}{|c|c|c|}
\hline Значення & Кількість & Частота \\
\hline as & 134 & $46 \%$ \\
\hline like & 141 & $48 \%$ \\
\hline seem & 17 & $6 \%$ \\
\hline Разом & 292 & $100 \%$ \\
\hline
\end{tabular}

Джерело: розроблено авторами

Наступним аспектом частотного аналізу було встановлення типів інтегральних ментальних просторів та їхне наповнення у поетичних твоpax усіх досліджуваних авторів. Найчастотнішими ментальними просторами є Людина, Природа та Абстрактні поняття, відповідно відсотково представлені: human - 141 (48,29\%); nature 104 (35,62\%); abstract notions - 32 (10,96\%).

Такі частотні дані підтверджують тезу про особливу роль у художній концептуалізації світу природи та людини, а також художньо-поетичного втілення взаємовідношення людини та природи, відображення природи людини, їі впливу на природне середовище та впливу природи на буття людини в англійській поезії початку XIX століття. Розподіл художніх порівнянь у поезії Колріджа, Шеллі та Кітса за виділеними ментальними просторами (рис. 4) та (таблиця 3).

Таблиця 3

Розподіл частотності художніх порівнянь у поезї Колріджа, Шеллі та Кітса за виділеними ментальними просторами

\begin{tabular}{|c|c|c|}
\hline Значення & Кількість & Частота \\
\hline abstract notions & 32 & 0,109589 \\
\hline death & 7 & 0,023973 \\
\hline god & 5 & 0,017123 \\
\hline human & 141 & 0,482877 \\
\hline language & 3 & 0,010274 \\
\hline nature & 104 & 0,356164 \\
\hline Разом & 292 & 1 \\
\hline
\end{tabular}

Джерело: розроблено авторами

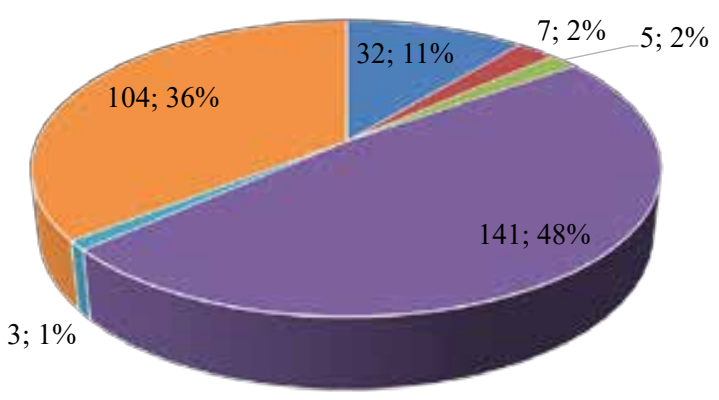

- abstract notions $\approx$ death $\approx$ god $\approx$ human $\approx$ language $\approx$ nature

Рис. 4. Розподіл частотності художніх порівнянь у поезї̈ Колріджа, Шеллі та Кітсаза виділеними концептуальними сферами

Джерело: розроблено авторами 
Частотність порівнянь, які е образно-поетичним втіленням конкретних художньо-поетичних концептів визначених ментальних просторів (таблиця 4). Як бачимо, найчастотніші концептуальні сфрери Людина та Світ відображені у високій частотності художньо-поетичних концептів тілесності, психо-емоційних параметрів людини, природних явищ та елементів живої та неживої природи, космічних об'єктів та просторових понять. Відповідно, лінгвокогнітивна репрезентація ментального простору Природа охоплюе такі художньо-поетичні концепти: міфологічні, надприродні істоти, людина, живі істоти в аспекті проявів їх зовнішнього вигляду, поведінки, чуттевості. Природоцентричні образи набувають антропоцентричного характеру.

\section{Частотне співвідношення ключових художніх концептів у поетичних контекстах}

\begin{tabular}{|c|c|c|}
\hline Значення & Кількість & Частота \\
\hline actions & 1 & $0,34 \%$ \\
\hline body & 25 & $8,56 \%$ \\
\hline celestial bodies & 2 & $0,68 \%$ \\
\hline communication & 1 & $0,34 \%$ \\
\hline creatures & 17 & $5,82 \%$ \\
\hline death (general) & 7 & $2,40 \%$ \\
\hline emotions and feelings & 48 & $16,44 \%$ \\
\hline emotions/feeling & 27 & $9,25 \%$ \\
\hline fantasy & 1 & $0,34 \%$ \\
\hline general & 1 & $0,34 \%$ \\
\hline god (general) & 5 & $1,71 \%$ \\
\hline hope & 5 & $1,71 \%$ \\
\hline human(general) & 8 & $2,74 \%$ \\
\hline joy & 1 & $0,34 \%$ \\
\hline landscape & 61 & $20,89 \%$ \\
\hline love & 1 & $0,34 \%$ \\
\hline mind/cognition & 9 & $3,08 \%$ \\
\hline morals & 31 & $10,62 \%$ \\
\hline natural elements & 4 & $1,37 \%$ \\
\hline natural forces & 8 & $2,74 \%$ \\
\hline other & 4 & $1,37 \%$ \\
\hline plant & 5 & $1,71 \%$ \\
\hline plants & 5 & $1,71 \%$ \\
\hline poesy and art & 9 & $3,08 \%$ \\
\hline poetic nerit & 2 & $0,68 \%$ \\
\hline poetry & 2 & $0,68 \%$ \\
\hline seasons & 1 & $0,34 \%$ \\
\hline society & 1 & $0,34 \%$ \\
\hline Разом & 292 & $100 \%$ \\
\hline
\end{tabular}

Джерело: розроблено авторами

Відповідно був проведений частотний аналіз розподілу ментальних просторів, концептосфер та художніх концептів у поезії конкретного автора. Виявлено, що в межах найпродуктивніших ментальних просторів Людина та Природа основна увага поетів приділена художній концептуалізації внутрішнього стану людини, чуттевому аспектові сприйняття довкілля, що створений, відповідно, на основі паралелізму між просто- ровими концептами та антропоцентричними концептами. Для поезії Джона Кітса також однією з продуктивних та домінантних виявилась ментальна сыера «Мова». У поезії Персі Біші Шеллі також вербалізовано ментальні простори «Смерть» та «Бог».

Наступним етапом дослідження було проведення аналізу структурно-композиційних форм художніх порівнянь у текстах визначених авторів. Було встановлено значне переважання композиційного порівняння (таблиця 5 та рис.4). Під композиційним порівнянням ми розуміемо стилістичний прийом констеляції, у якому суб'єкт, об’єкт та причина порівняння розширені додатковими смисловими комплексами або виражені імпліцитно. Наприклад:

A lay that once I saw her hand awake,/Her form seems floating palpable, and near:/ Had I e'er seen her from an arbour take/A dewy flower, oft would that hand appear,/And o'er my eyes the trembling moisture shake; Hast thou from the caves of Golconda, a gem / Pure AS the ice-drop that froze on the mountain?/Bright as the humming-bird's green diadem,/When it flutters in sunbeams that shine through a fountain?

\section{Структурно-композиційні параметри художніх порівнянь у поетичних контекстах}

\begin{tabular}{|l|c|c|}
\hline \multicolumn{1}{|c|}{ Значення } & Кількість & Частота \\
\hline compositional & 168 & $57,53 \%$ \\
\hline multicomponential & 104 & $35,62 \%$ \\
\hline three-componential & 20 & $6,85 \%$ \\
\hline Разом & 292 & $100 \%$ \\
\hline
\end{tabular}

Джерело: розроблено авторами

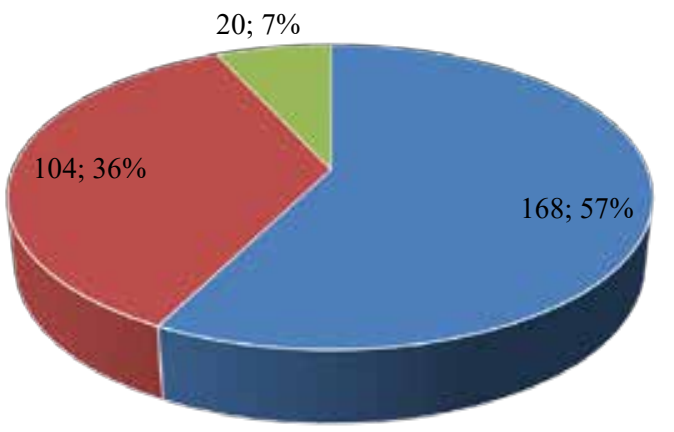

- compositional $\|$ multicomponential $\|$ three-componential

Рис. 5. Структурно-композиційні параметри художніх порівнянь у поезії Семюела Тейлора Колріджа, Персі Біші Шеллі та Джона Кітса

Проведений аналіз структурно-композиційних та семантичних аспектів процесів художньої концептуалізації у системі художніх порівнянь становить підгрунтя визначення художньо-естетичних принципів світогляду англійських поетів початку XIX століття. Відповідно, домінантними концептуальними сфрерами є природа, людина і світ, актуалізованими у системі художньо-поетичних концептів, які виявляють антропоцентричний ха- 
рактер поетичного відображення реальності, виділенні чуттєвих, психо-емоційних, ментальних характеристик суб'єкта поетичного зображення, людиностпрямований образ світу в англійському поетичному дискурсі визначеного періоду.

Висновки. За даними корпусного дослідження виявлено структурні та семантичні особливості художнього порівняння в англійському поетичному дискурсі початку XIX століття. Для мети дослідження був укладений корпус поетичних текстів вказаного історичного періоду, який охоплюе авторські підкорпуси поетичних текстів, загальна кількість слововживань у яких становить 50000 слів. Створений та розмічений корпус текстів та відповідні програмні інструменти дали змогу виконати частотний аналіз лексичних засобів вербалізації виділених у текстах кожного автора художніх концептів та пошук і семантичний аналіз порівняльних засобів вербалізащії цих концептів та здійснити їхню класифрікацію.

У результаті дослідження було отримано дані про конфігурацію та частотність поріняльних засобів вербалізації інтегральних концептуальних / ментальних полів та художніх концептів англійської поезії початку XIX століття; встановлено співвідношення лексико-граматичних ти- пів порівнянь, визначених на основі сполучного компонента порівняння (like, as, seem); виявлено та описано основні ментальні простори та їхне концептуальне наповнення у поетичних творах усіх досліджуваних авторів; проведено аналіз структурно-композиційних форм художнього порівняння. Проведений аналіз структурно-композиційних та семантичних аспектів художньої концептуалізащії у системі художніх порівнянь був покладений в основу визначення художньоестетичних принципів світогляду англійських поетів початку XIX століття. Відповідно, домінантними концептуальними сфрерами $є$ природа, людина і світ, актуалізованими у системі художньо-поетичних концептів, які виявляють антропоцентричний характер поетичного відображення реальності, у якому переважають чуттеві, психо-емоційні, ментальні характеристики суб'єкта поетичного зображення, людиностпрямований образ світу в англійському поетичному дискурсі визначеного історичного періоду. Застосування корпусних технологій $є$ продуктивним інструментом у дослідженні поетичного тексту. Здійснена розмітка корпусу та його анотування в подальшому можуть лягти в основу укладання словників художніх порівнянь.

\section{Список літератури:}

1. Демська О.М. Текстовий корпус: ідея іншої форми. Київ : Вид. дім «Києво-Могилянська академія», 2011.284 с.

2. Ікалюк Л.М. Лексико-семантична сполучуваність компонентів порівняльних конструкцій у текстах давньоанглійської мови. Гуманітарний вісник : [всеукр. зб. наук. праць]. Серія : Інозелна фбілологія. Черкаси : Видавництво ЧДТУ, 2009. Вип. 13. С. 131-135.

3. Кривенко Г.Л. Зоосемізми в англійській та українській мовах: семантико-когнітивний і функціональнопрагматичний аспекти : автореф. дис. ... канд. філол. наук : 10.02 .17 «Порівняльно-історичне і типологічне мовознавство». Київ, 2006. 24 с.

4. Кульчицький I.M. Технологічні аспекти укладання корпусів текстів. Дані текстових корпусів у лінгвістичних дослідженнях : монографбія / В.А. Широков, І.В. Шевченко, А.П. Загнітко та ін. ; за ред. О.П. Левченко. Львів : Вид-во Львівської політехніки, 2015. С. 29-45.

5. Левченко О.П., Бутельський Я.Ю. Гендерні особливості української художньої прози (за даними аналізу частотності колокацій у текстах 60-80-х та 2000-х років). XX-XXI століття: жанровостильові й лінгвістичні металорфози в украӥнській мові та літературі : монографія. Оломоуць : Університет ім. Ф. Палацького в Оломоуці, 2016. С. 299-334.

6. Маковецька-Гудзь Ю.А. Семантико-граматичні моделі художніх порівнянь (на матеріалі української поетичної мови 70-90-х років XX століття) : автореф. дис. ... канд. фрілол. наук : 10.02.01 - укр. мова. Київ, 2010.22 с.

7. Найда А.М. Стійкі народні порівняння як об'єкт фрразеології (семантичний і структурний аспекти) : авторедр. дис. ... канд. фрілол. наук : 10.02.01 - укр. мова. Дніпропетровськ, 2002. 23 с.

8. Павлюк Т.П. Порівняльні звороти в сучасному українському поетичному тексті : автореф. дис. ... канд. філол. наук : 10.02 .01 - укр. мова. Запоріжжя, 2011. 21 с.

9. Талько С.В. Лінгвоаксіологічна семантика антропоцентричних метафор та порівнянь в українській і англійській мовах : автореф. дис. ... канд. фрілол. наук : 10.02 .17 - порівняльно-історичне і типологічне мовознавство. Київ, 2009. 22 с.

10. Тищенко-Монастирська О.О. Порівняння в тексті фольклору (на матеріалі української, російської, кримськотатарської і татарської мов) : авторедр. дис. ... канд. фрілол. наук : 10.02 .15 - загальне мовознавство. Київ, 2010. 22 с.

11. Філінюк В.А. Порівняльні конструкцї в поетичному ідіолекті Миколи Дмитренка. Філологічний дискурс : зб. наук. праць. Хмельницький : Хмельницька гуманітарно-педагогічна академія, 2015. Вип. 2. С. 119-123.

12. Шевчук А.В. Принципи лексикографрічного опису зоонімів у словниках сучасної англійської мови : автореф. дис. ... канд. фрілол. наук : 10.02.04 - герм. мови. Запоріжжя, 2016. 22 с.

13. Ярова Н.В. Компаративні блоки у сучасній американській поезії: лінгвокогнітивний аспект : автореф. дис. ... канд. фрілол. наук : 10.02 .04 - герм. мови. Київ, 2003. 23 с.

14. McEnery T., Hardie A. Corpus linguistics: method, theory and practice. Cambridge : Cambridge University Press, 2012. $294 \mathrm{p}$.

15. Meyer Ch.F. English corpus linguistics. An introduction. Cambridge : Cambridge University Press, 2002.168 p.

16. Romanyshyn N. Application of computer technologies in conceptual analysis 2018 IEEE 13th International Scientific and Technical Conference on Computer Sciences and Information Technologies (CSIT), vol. 2, pp. 55-57.

17. Romanyshyn N. Application of Corpus Technologies in Conceptual Studies (based on the Concept Ukraine Actualization in English and Ukrainian Political Media Discourse). COLINS. 2020. Pp. 472-488. 


\section{References:}

1. Demska O.M. (2011) Tekstovyi korpus: ideia inshoi formy [Text corpus: the idea of another form]. Kyiv: Kyiv-Mohyla Academy. (in Ukrainian)

2. Ikaliuk L.M. (2009) Leksyko-semantychna spoluchuvanist komponentiv porivnialnykh konstruktsii u tekstakh davnoanhliiskoi movy [Lexical-semantic compatibility of components of comparative constructions in Old English texts]. Humanitarian Bulletin, vol. 13, pp. 131-135.

3. Kryvenko H.L. (2006) Zoosemizmy v anhliiskii ta ukrainskii movakh: semantyko-kohnityvnyi i funktsionalnoprahmatychnyi aspekty [Zoosemisms in English and Ukrainian: semantic-cognitive and functional-pragmatic aspects]. Porivnialno-istorychne i typolohichne movoznavstvo [Comparative-historical and typological linguistics]. Kyiv, p. 24.

4. Kulchytskyi I.M. (2015) Tekhnolohichni aspekty ukladannia korpusiv tekstiv [Technological aspects of composing corpora of texts]. Dani tekstovykh korpusiv u linhvistychnykh doslidzhenniakh: monohrafiia [Data of text corpora in linguistic research: monograph]. Lviv: Publishing House of Lviv Polytechnic National University, pp. 29-45.

5. Levchenko O.P. (2016) Henderni osoblyvosti ukrainskoi khudozhnoi prozy (za danymy analizu chastotnosti kolokatsii u tekstakh 60-80 ta 2000 rokiv) [Gender features of Ukrainian fiction (according to the analysis of the frequency of collocations in the texts of the 60-80s and 2000s)]. XX-XXI stolittia: zhanrovostylovi y linhvistychni metamorfozy $v$ ukrainskii movi ta literaturi: monohrafiia [XX-XXI centuries: genre-style and linguistic metamorphoses in the Ukrainian language and literature: monograph]. Olomouts: Palatsky University, pp. 299-334.

6. Makovetska-Hudz Yu.A. (2010) Semantyko-hramatychni modeli khudozhnikh porivnian (na materiali ukrainskoi poetychnoi movy 70-90 rokiv XX stolittia) [Semantic and grammatical models of artistic comparisons (on the material of the Ukrainian poetic language of the 70-90s of the XX century)]. Kyiv, p. 22.

7. Naida A.M. (2002) Stiiki narodni porivniannia yak ob iekt frazeolohii (semantychnyi i strukturnyi aspekty) [Stable folk comparisons as an object of phraseology (semantic and structural aspects)]. Dnipropetrovsk, p. 23.

8. Pavliuk T.P. (2011) Porivnialni zvoroty v suchasnomu ukrainskomu poetychnomu teksti [Comparative inversions in the modern Ukrainian poetic text]. Zaporizhzhia, p. 23.

9. Talko S.V. (2009) Linhvoaksiolohichna semantyka antropotsentrychnykh metafor ta porivnian $v$ ukrainskii $i$ anhliiskii movakh [Linguoaxiological semantics of anthropocentric metaphors and comparisons in Ukrainian and English]. Kyiv, p. 22.

10. Tyshchenko-Monastyrska O.O. (2010) Porivniannia v teksti folkloru (na materiali ukrainskoi, rosiiskoi, krymskotatarskoi $i$ tatarskoi mov) [Comparison in the text of folklore (on the material of Ukrainian, Russian, Crimean Tatar and Tatar languages)]. Kyiv, p. 22.

11. Filiniuk V.A. (2015) Porivnialni konstruktsii v poetychnomu idiolekti Mykoly Dmytrenka [Comparative constructions in the poetic idiolect of Mykola Dmytrenko]. Philological discourse: a collection of scientific papers, vol. 2, pp. 119-123.

12. Shevchuk A.V. (2016) Pryntsypy leksykohrafichnoho opysu zoonimiv u slovnykakh suchasnoi anhliiskoi movy [Principles of lexicographic description of zoonyms in dictionaries of modern English]. Zaporizhzhia, p. 22.

13. Yarova N.V. (2003) Komparatyvni bloky u suchasnii amerykanskii poezii: linhvokohnityvnyi aspect [Comparative blocks in modern American poetry: the linguocognitive aspect]. Kyiv, p. 23.

14. McEnery T., Hardie A. (2012) Corpus linguistics: method, theory and practice. Cambridge: Cambridge University Press, p. 294

15. Meyer Ch.F. (2002) English corpus linguistics. An introduction. Cambridge: Cambridge University Press, p. 168.

16. Romanyshyn N. (2018) Application of computer technologies in conceptual analysis. Proceedings of the IEEE 13th International Scientific and Technical Conference on Computer Sciences and Information Technologies (CSIT), vol. 2 , pp. $55-57$.

17. Romanyshyn N. (2020) Application of Corpus Technologies in Conceptual Studies (based on the Concept Ukraine Actualization in English and Ukrainian Political Media Discourse). COLINS, pp. 472-488. 